\title{
HAEMATOLOGICAL AND BIOCHEMICAL ALTERATIONS IN ENZOOTIC BOVINE HAEMATURIA
}

\author{
M. C. PRASAD
}

Division of Pathology, Indian Veterinary Research Institute, Izatnagar, 243122, India

Received fuly 7, 1981

\begin{abstract}
Prasad, M. C.: Haematological and Biochemical Alterations in Enzootic Bovine Haematuria. Acta vet. Brno, 52, 1983: 157-161.

Haematological and biochemical alterations in the serum of EBH cattle were studied. Haemogram was indicative of progressive anaemia and leukopenia. There was an increase in the levels of blood urea nitrogen and serum creatinine on one hand while on the other hand decreased levels of serum protein, blood sugar, cholesterol and calcium were observed. The urine samples of these animals were positive for albumin, sugar, pus cells and casts. The condition was attributed to be of multifactorial etiology with the involvement of kidney and liver.
\end{abstract}

Haemogram, blood chemistry, urine.

Studies on haematological and biochemical alterations have often provided certain clues on the etiopathogenesis of the ailments particularly those of "obscure" etiology. Keeping this in view and considering the world-wide prevalence (enzootic pockets) of Enzootic Bovine Haematuria $(\mathrm{EBH})$, its worst prognosis and obscure nature of etiological agent (s), an attempt has been made to study the various alterations in haematological and biochemical parameters in spontaneous cases.

\section{Materials and Methods}

Seven adult cattle ( 4 bullocks and 3 cows) of nondescript breed suffering from EBH were purchased from Sundarkhal area (near Mukteswar) of Kumaon Hills. The animals were aged 7-10 years. Two adult bullocks of almost similar age group were used as healthy control. Both groups were fed standard ration prepared and supplied by the institute and ad lib. water. These animals were kept under observation for about a week before experimentation and during this period body temperature, pulse, respiration and general body condition were recorded and found to be well within normal range.

Blood was collected from jugular vein and various haematological and biochemical estimations were carried out for seven and six consecutive months at monthly intervals in case of haematuric and control animals, respectively. Thus, a total of 49 observations were taken in haematuric animals and 12 in control animals (excluding the initial observations taken prior to putting them under experiment). For different haematological parameters (total erythrocyte/leucocyte count, differential leucocyte count, haemoglobin estimation, packed cell volume, mean corpuscular volume, mean corpuscular haemoglobin and mean corpuscular haemoglobin concentration) the techniques described by Coles (1974) were employed. Biochemical studies included total protein (Biuret method - Wootten 1964), blood sugar (Folin and Wu 1920), blood urea nitrogen (Diacetyl monoxime, Delory 1966), serum creatinine (Wootten 1964), inorganic phosphorus (Fisk and Subbarao 1925), calcium (Clark and Collip 1925) and total cholesterol (Wootten 1964) estimations. Simple arithmetical mean of these values was calculated.

The urine samples were examined routinely at fortnightly intervals (Coles 1974). 


\section{Results}

The results of various haematological and biochemical examinations of haematuric and control animals have been presented in Tables 1 and 2. These observations are based on seven animals and forty nine observations in case of haematuric animals and two animals and twelve observations in case of control group. A graphical presentation of various biochemical parameters has been depicted in Fig. 1 and 2.

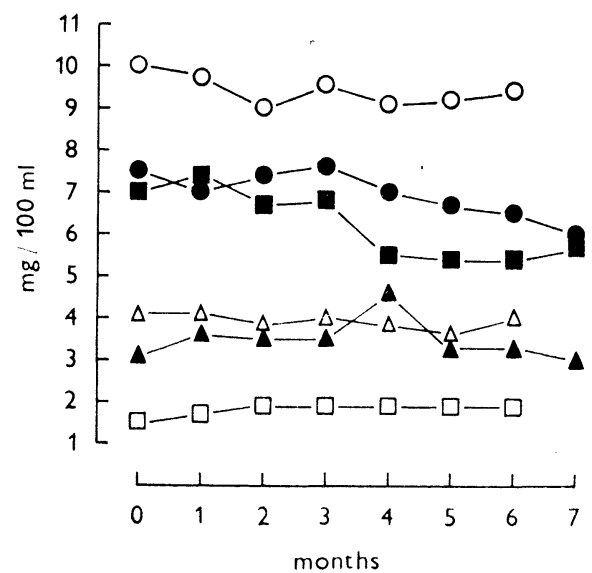

Fig. 1

Serum calcium, inorganic phosphorus and creatinine values at various time intervals in control and haematuric animals; -1 and - - (Calcium), $\Delta-\Delta$ and $\Delta$ (inorganic phosphorus), $\square-\square$ and $\square-\ldots$ (creatinine), open symbols - controls; closed symbols - haematuric animals.

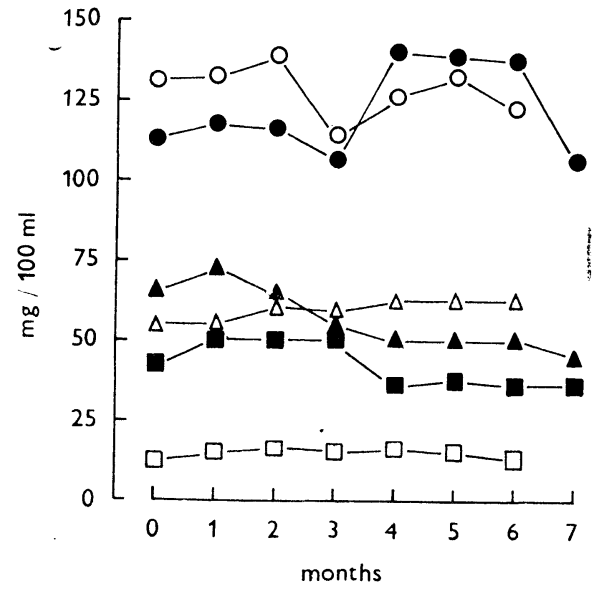

Fig. 2

Blood sugar, cholesterol and BUN level at various time interval in control and haematuric animals; 0 and (Cholesterol), $\triangle-\triangle$ and $\Delta-\Delta$ (blood sugar), $\square-\square$ and - (BUN) open symbols - controls, closed symbols - haematuric animals.

Table 1

Haemogram of healthy control and EBH animals (Mean S. E.)

\begin{tabular}{|l|r|r|}
\hline \multicolumn{1}{|c|}{ Parameters } & Healthy controls & EBH animals \\
\hline & & \\
\hline Total erythrocyte count (million/mm $\mathrm{mm}^{*}$ & $6.97 \pm 0.07$ & $4.63 \pm 0.10$ \\
Haemoglobin (gm/dl)* & $9.18 \pm 0.14$ & $6.81 \pm 0.31$ \\
Packed cell volume $(\%)^{*}$ & $30.66 \pm 0.61$ & $21.07 \pm 0.48$ \\
MCV $(\mathrm{C} \mu)^{*}$ & $65.31 \pm 1.59$ & $45.58 \pm 0.75$ \\
MCH $(\mu$ microgram) & $13.11 \pm 0.21$ & $14.68 \pm 0.52$ \\
MCHC $(\%)$ & $29.96 \pm 0.50$ & $32.18 \pm 1.24$ \\
Total leucocyte count (thousand $/ \mathrm{mm})^{*}$ & $8.36 \pm 0.12$ & $5.03 \pm 0.15$ \\
Differential leucocyte count & & \\
Lymphocyte* & & $51.10 \pm 2.20$ \\
Neutrophil* & $59.66 \pm 0.66$ & $42.97 \pm 1.9$ \\
Eosinophil & $36.50 \pm 0.95$ & $3.22 \pm 0.25$ \\
Monocyte & $3.33 \pm 0.76$ & $1.90 \pm 0.21$ \\
Basophil & $0.16 \pm 0.16$ & $0.15 \pm 0.7$ \\
\hline
\end{tabular}

* Significant at $5 \%$ probability level 


\begin{tabular}{|l|r|r|}
\hline \multicolumn{1}{|c|}{ Parameters } & Healthy controls & EBH animals \\
\hline Serum protein $(\mathrm{gm} \%)^{*}$ & $6.98 \pm 0.06$ & $5.16 \pm 0.10$ \\
Blood sugar $(\mathrm{mg} \%)$ & $60.25 \pm 0.77$ & $55.53 \pm 3.99$ \\
Cholesterol (mg\%) & $128.58 \pm 3.03$ & $120.36 \pm 6.19$ \\
Blood urea nitrogen $(\mathrm{mg} \%)^{*}$ & $15.71 \pm 0.33$ & $41.65 \pm 3.5$ \\
Serum creatinine $(\mathrm{mg} \%)^{*}$ & $1.96 \pm 0.03$ & $6.16 \pm 0.31$ \\
Inorganic phosphorus $(\mathrm{mg} \%)$ & $3.90 \pm 0.08$ & $3.71 \pm 0.19$ \\
Calcium (mg \%) & $9.40 \pm 0.10$ & 6.88 \\
\end{tabular}

* Significant at $5 \%$ probability level

The urine samples of haematuric animals were pale yellow to dark red in colour and invariably alkaline in reaction. The specific gravity ranged between 1010-1030. These were positive $(+/++)$ both for sugar and albumin. Microscopical examination of urinary sediments exhibited the presence of erythrocytes, phosphate (triple) crystals and pus cells in haematuric animals. Bacteriological examination of urine samples did not reveal any significant result.

\section{Discussion}

The haemogram was indicative of progressive anaemia and leukopenia. Anaemia was attributed to blood loss through urine. Similar observations were reported by a number of previous workers (Datta 1953; Mugera and Nerito 1968; Singh et al. 1973; Singh et al. 1974; Rajendran et al. 1979). Further, the role of bone marrow depressants (toxicosis and radiation) in the pathogenesis of anaemia can not be ruled out especially in EBH cases as bracken fern is thought to contain certain radiomimetic substances (Evans et al. 1954; Clarke and Garner 1967) and evidence is there to correlate the association of bracken fern with EBH (Rosenberger and Heeschen 1969; Price and Pamukcu 1968).

Leucopenia, particularly mild lymphopenia associated with neutrophilia was observed in the present study. Certain viral diseases, stress, ionizing radiation and the use of immunosuppressive drugs causes lymphopenia while alterations (depletion and destruction) in bone marrow are said to produce leucopenia (Coles 1974). He further mentioned that factors stimulating a typical stress reaction like metabolic disturbances, toxicosis, haemorrhages and tissue destruction are known to cause neutrophilia. The role of above factors in EBH needs further study and experimental elucidation.

A significant increase in the level of blood urea nitrogen and serum creatinine supports the contention of Singh et al. (1973), Singh et al. (1974) and Teotia et al. (1974) that kidney is involved in the pathogenesis of EBH. This is also supported by the results observed in routine examination of urine samples of haematuric animals which were positive for albumin, sugar, pus cells, and casts. Considerably decreased levels of serum protein, blood sugar, cholesterol and calcium observed in haematuric animals indicated hepatic involvement also in the etiopathogenesis of EBH.

Evidences are there to show the association of virus (O1s on et al. 1959, 1962, 1969; Brobst and Olson 1965; Kaminjolo et al. 1972), fungus (Datta 1965), 
dietetie deficiency/excess (Moulton 1978) and bracken fern (S mith and Beatson 1970) with the etiopathogenesis of EBH. On the basis of present study it may be said that $\mathrm{EBH}$ is a syndrome complex where kidney and/or liver are involved and might be of multifactorial etiology having at least one common symptom of haematuria.

\section{Hematologické a biochemické změny při enzootické bovinní hematurii}

Změny haematologických a biochemických ukazatelů $\mathrm{v}$ krevním séru skotu při enzootické bovinní hematurii byly sledovány na 7 zvíratech obojího pohlaví ve stáŕi 7 až 10 let a srovnávány s nálezy u 2 býků kontrolních. Hemogram neınocných zviŕat ukazoval progresivní anémii a leukopénii. Byla zvýšena koncentrace močoviny $\mathrm{v}$ krvi (BUN) a kreatinu $\mathrm{v}$ séru, zatímco množství bílkovin $\mathrm{v}$ séru, koncentrace glukózy $\mathrm{v}$ krvi, cholesterolu a vápníku byly sníženy. $\mathrm{V}$ moči zviřat byl nalezen albumin, cukr, hnisové buňky a odlitky. Tento nález je zřejmě multifaktoriálního původu a vyplývá $\mathrm{z}$ onemocnění jater a ledvin.

\section{Гематслогические и биохимические изменения при энзоотической гематурии крупного рогатого скота}

Изменения гематологических и биохимических показателей в кровяной сыворотке при энзоотической гематурии крупного рогатого скота были исследованы на 7 животных обоего пола в возрасте 7-10 лет и проводились сравнения с 2 контрольными быками. Гемограмма больных животных выявляла прогрессивную анемию и лейкопению. Наблюдалась повышенная концентрация мочевины в крови (BUN) и креатинина в сыворотке, между тем как количество белков в сыворотке, концентрация глюкозы в крови, холестерина и кальция были понижены. В моче животных был установлен альбумин, сахар, гнойные клетки и отливки. Данные результаты являются, видимо, многофакторного происхождения и вытекают из болезни печени и почек.

\section{Acknowledgement}

The author is thankful to Dr. B. S. Rajya, the then Head, Division of Pathology for his keen interest and the necessary facilities provided. The help extended by Sri Ram Pal and Dal Chand in the maintenance of experimental animals are duly acknowledged.

\section{References}

BROBST, D. F. - OLSON, C.: Histopathology of urinary bladder tumours induced by bovine cutaneous papilloma agent. Cancer Res., 25,, 1965: 12-19.

CLARK, E. P. - COLLIP, J. B.: A study of the Tisdall Method for the determination of blood serum calcium with suggested modification. J. biol. Chem., 63, 1925: 461-464.

CLARKE, E. G. C. - CLARKE, M. L.: Garner's Veterinary Toxicology. Bailliére, Tindall Casell, 3rd ed., London, 1967, pp. 342-346.

COLES, E. H.: Veterinary Clinical Pathology, W. B. Saunders Co., 2nd Ed., 1974, Philadelphia, London, Toronto.

DATTA, S.: Chronic bovine haematuria. Indian Vet. J., 30, 1953: 1-33, 96-109, 117-189, $283-301,388-406$.

DATTA, S.: Enzootic bovine haematuria. Indian J. Vet. Sci. 35, 1965: 69-82. 
DELORY, G. E.: Colorimetry in Clinical Biochemistry. Hilger and Watts Ltd., Ist. Ed., London, 1966.

EVANS, W. C. - EVANS, E. T. R. - HUGHES, L. E.: Studies on bracken fern poisoning in cattle, part-II, British Vet. J., 110, 1954: 365-380.

FISKE, C. H. - SUBBAROW, Y.: The colorimetric determination of phosphorus. J. biol. Chem., 66, 1925:375-379.

FOLIN, O. - WU, H.: A system of blood analysis - a simplified and proved method for determination of sugar. J. biol. Chem., 41, 1920: 367-370.

KAMINJOLO, J. S. - MUGERA, G. M. Jr. - ROSTED, A. F.: Isolation of a herpes type virus from some tumours of bovine origin. Zbl. Vet. Med. B., 19, 1972: 626-632.

MOULTON, J. E.: Tumors in Domestic Animals, University of California Press, Berkeley, Los Angeles, London, 2nd ed. 1978, pp. 303-308.

MUGERA, G. M. - NERITO, P.: Tumours of urinary bladder and liver associated with enzootic haematuria in Kenya cattle Vet. Rec., 83, 1968: 457-459.

OLSON, C. - PAMUKCU, A. M. - BROBST, D. F. - KOWALCZYK, T. - SATTAR, E. J. - PRICE, J. M.: An urinary bladder tumour induced by a bovine cutaneous papilloma agent. Cancer Res., 19, 1959: 779-782.

OLSON, C. - LUCEDKE, A. J. - BROBST, D. F. : Induced immunity of skin, vagina and urinary bladder to bovine papillomatosis. Cancer Res., 22, 1962: 463-468.

OLSON, C., et al.: Environ. Hlth. 19, 327 (cited by McKenzie, R. A.: Australian Vet. J. 54, 1978: $61-64)$.

PRICE, J. M. - PAMUKCU, A. M.: The induction of neoplasm of the urinary bladder of the cow and the small intestine of the rats by feeding bracken fern (P. aquilina) Cancer Res., 28, 1968: $2247-2251$.

RAJENDRAN, M. P. - VIRARAGHAVAN, K. - CHENNUKESAVALU, M. - DAMODARAN, S.: Enzootic bovine haematuria in Tamil Nadu. Indian Vet. J., 56, 1979: 716-721.

ROSENBERGER, G. - HEESCHEN, W.: Adlerfarn, die Ursache des sog. Stallrotes der Rinder. Dtsch. Tierärztl. Wschr. 67, 1960: 201-208.

SINGH, A. K. - JOSHI, H. C. - RAY, N.: Studies on bovine haematuria I. Haematological and biochemical observations on the blood of cattle suffering from haematuria. Indian J. Anim. Sci., 43, 1973: 296-299.

SINGH, B. P. - JOSHI, H. C. - PRASAD, B.: Haematological and biochemical investigation in chronic bovine haematuria. Indian Vet. J., 51, 1974: $365-370$.

SMITH, B. L. - BEATSON, N. S.: Bovine enzootic haematuria in New Zealand. New Zealand Vet. J., 18, 1970: 115-120.

TEOTIA, D. S. - JOSHI, H. C. - RAY, S. N.: Studies on bovine haematuria 2. Biochemical analysis of blood and urine of cattle suffering from haematuria. Indian J. Anim. Sci., 43, 1973: $620-624$.

WOOTTEN, I. D. P.: Micro-analysis in Medical Biochemistry, 4th Ed. 1964. J \& A. Churchill Ltd., London. 